\title{
POLICY RESPONSES TO WORKFORCE AGEING - EXISTING, POTENTIAL AND A REPORT CARD FOR NEW ZEALAND
}

\author{
Judith A. Davey \\ Senior Associate, \\ Institute for Governance and Policy Studies, \\ Victoria University of Wellington
}

\begin{abstract}
Arguments for encouraging prolonged participation in the paid workforce by older people, based on individual, social, economic and business benefits, are set out in the literature and reflected in public policy. Individual decisions about participation are influenced by external factors and personal attributes. The ability to realise aspirations and preferences in the labour market depends on the social, economic and policy context and on employers' actions and attitudes. Drawing on local and international literature as well as interviews with employers and representatives of public and private sector organisations, this paper examines policy responses to workforce ageing; both current and potential initiatives. Many of these relate to fiscal concerns and focus on retirement income policy; others aim to influence the behaviour of employers or to assist older workers. This leads to comment on and an evaluation of the New Zealand policy context with respect to workforce ageing.
\end{abstract}

\section{Introduction}

Arguments for encouraging prolonged participation in the paid workforce by older people, based on individual, social, economic and business benefits, are set out in the literature and reflected in public policy throughout the world. Individual decisions about labour market participation are influenced by external factors as well as personal attributes. The ability to realise aspirations and preferences in the labour market depends on the social, economic and policy context and on employers' actions and attitudes. This paper focuses on the influence of policy settings - those which are currently in operation in New Zealand and overseas initiatives. Many of these relate to fiscal concerns and therefore focus on retirement income policy (having indirect effects on the labour force); others aim to influence the behaviour of employers or to assist older workers. In conclusion, the paper comments on and seeks to evaluate the New Zealand policy context with respect to workforce ageing.

The material is drawn from the findings of the paid employment objective of Making Active Ageing a Reality, a research project undertaken through the University of Waikato, funded by the Ministry of Business, Innovation and Employment. This research incorporated a review of relevant New Zealand and overseas academic, policy-related and business literature on workforce ageing as well as investigative interviews carried out in mid-2013 in Auckland, Hamilton, Wellington and Christchurch. Working through the New Zealand Institute of Management and other contacts, 33 employers were interviewed, from a range of industries with workforces from under ten to several thousand. In addition, 26 key informants, from professional, commercial, trade union and public sector organisations involved in labour market issues and policies contributed their views on workforce ageing and the policy context. 


\section{Current central government policies which impact on workforce participation}

\section{Pension Policies}

Governments in many countries are adjusting pensions and retirement policies in response to the fiscal pressures of population ageing, but also, as a linked objective, to encourage higher levels of labour force attachment by older people (OECD 2006). Increases in longevity have produced a widened gap between the age of eligibility for pension support and life expectancy (Howse 2006). These trends also contribute to labour shortages as more people leave the workforce and fewer young people enter. Policy responses, singly or in combination, include raising the age at which pensions and other benefits can be claimed; cutting back entitlements; allowing more flexibility in combining work and pensions; taxation changes and actuarial adjustments (Riach 2006; OECD 2006). Such initiatives lie within a wider policy frame responding to the overall implications of population ageing: the necessity of developing appropriate macro-economic policies; enhancing productivity; achieving a well-functioning labour market and greater workforce attachment over the whole life course (OECD 2006; Beard et al 2012).

Striking the right balance between guaranteeing an adequate income for older workers, while not undermining work incentives, is a challenge. In New Zealand, McGregor (2007, p.4) also made this link - "the issue of retirement income cannot easily be separated from the issue of the employment of older workers both economically and socially. "

Several countries have raised pension or mandatory retirement ages, or adopted a flexible regime. For example, in Australia access to the aged pension is rising to 67 years by 2023 and the preservation age (access to superannuation) is rising to 60 by 2024. This is clearly a major policy lever to extend workforce participation. In New Zealand the raising of New Zealand Superannuation (NZS) eligibility age from 60 to 65 in the 1990s coincided with a marked increase in workforce participation in this age group (Hurnard 2005).

Not having a contributory retirement income system (until recently) makes the New Zealand environment different from most OECD counties. NZS, available on a universal basis from age 65, provides a high replacement income for low-income earners and beneficiaries and a moderate replacement income for average-wage earners. The higher the replacement rate the greater the incentive to leave the labour force. Research suggests that the current level of NZS is sufficient to assure the majority of older people a basic living income. However, expectations of higher living standards in retirement, especially among the oncoming baby boom generation, are likely to encourage people to remain in paid work, in some form, after receiving NZS, especially given higher life expectancy, which means that savings have to last longer.

It is possible to continue in paid work while receiving NZS. When asked for their views on this policy, the Active Ageing respondents articulated two standpoints. One argument supports current settings, on the basis that people earn NZS through a lifetime of contribution and paying taxes. To withhold NZS would discourage people from paid work when they might be keen to continue. From the employers' point of view this could remove valued workers. "It would turn people off work if they lost their pension, but they need a pension if they are working part-time. And we need people to work as the workforce is shrinking." Other respondents supported means-testing or withholding NZS from people in full-time paid work. One expressed a personal dilemma. "I feel it is double dipping. My conscience says should I not sign up for NZS. But I have 
worked all my life for this - is it my right?". Several respondents pointed out that present settings help to ease the transition from work to retirement by combining NZS with income from part-time work to support a comfortable lifestyle.

There was division among the Active Ageing respondents on whether age of eligibility for NZS should be raised. Some thought it was marginal to business concerns and only one factor in decisions about retirement. However they acknowledged that the age of eligibility is often seen, and commonly referred to, as "retirement age." Some respondents were against raising the age as it would force older people to work, sometimes unwillingly. "There always will be people who don't want to keep working for physical and mental reasons. It can't be good for employers if the age goes up and there are disengaged workers - creating a health and safety risk." Despite such concerns, many respondents felt that a rise in the age of eligibility was inevitable.

\section{Retirement}

Compulsory retirement has been abandoned in many countries, but others still retain this policy. In New Zealand, the Human Rights Act (HRA) came into effect in February 1999. Section 22 forbids employers from discriminating against suitably qualified job applicants on a number of grounds, including age. Its provisions apply to all aspects of employment - recruitment, selection, remuneration, training, promotion, transfers, retirement and termination, and ban compulsory retirement.

The Active Ageing informants were asked if they favoured the abolition of compulsory retirement. Although some saw that a fixed retirement age could be beneficial for employers to deal with difficult cases, the general opinion was against compulsion. Some pointed out that older workers always had and always would continue to work despite there being a "retirement age", in perception or in policy. Two main issues were raised. Firstly, that it was unjust to force people to retire when they wished to continue to work and when their employers wanted to keep them. Secondly, how could employers deal with the problem of underperforming older workers? Previously, a fixed retirement age allowed them to be exited without question. Now this option is not available. The alternative is for non-performing workers to be "managed out" and this, in the opinion of most respondents required tricky and difficult "conversations" which could be misunderstood on both sides.

\section{Age discrimination}

The workplace provides the most common grounds for complaints of age discrimination, which predominantly involve older people (although younger people are not exempt). Its existence in New Zealand is clear from numerous reports (Murray 2002; EEO Trust 2006; OGC 2013). Age discrimination, especially in hiring, is clearly a barrier to tackling workforce ageing. Leeson (2006) points out that acknowledging age discrimination has lagged behind recognition of other forms of unfairness and that it is unlikely to be addressed by market mechanisms. However, demographic and market trends, especially tightening in labour supply, may now mean that economic necessity is converging with requirements for social justice (Riach 2006).

Despite being effective in outlawing compulsory retirement, the New Zealand Human Rights Act did not appear to have an immediate effect on the prevalence of age discrimination (McGregor 2001; Wood, Harcourt and Harcourt 2004). The difficulty of proving that discrimination has 
occurred is a universal problem. Critics of anti-age discrimination legislation believe that it does not change employers' behaviour, but simply leads to more subtle and covert ways of discriminating and that stereotypical expectations surrounding age and retirement ("only a few years to go", "younger people deserve the work more") may inhibit older workers from challenging ageism. These views were reflected in the responses of the Active Ageing informants. The majority agreed that much age discrimination is not overt and may even be unrecognised. "Sometimes people don't know they are doing it. They employ people like themselves who they are comfortable with". The respondents agreed that the main area of discrimination against older workers is in recruitment, especially when they seek to re-enter the workforce. Several laid the blame at the doors of recruitment agencies, which tend to offer what they believe is palatable to employers. It is sometimes unclear whether age discrimination is real or whether decisions made by employers simply reflect real drawbacks of older workers in terms of their physical and mental capacities and outdated skills. "When you can't do things because of your age, the individual might see this as discrimination."

\section{Flexible work}

When the Active Ageing respondents were asked: "What kinds of work practices make it easier for older people to stay in the paid workforce and what makes it harder?" the most common responses were around flexible work practices. These included longer breaks and holidays; shorter hours, on a daily, weekly or annual basis; choices about night or shift work; and working at home.

Legislation on flexible working conditions has mostly been related to child care responsibilities or to provide opportunities for education and training (Heathrose Research 2010). But there is growing interest in how flexible work arrangements can address other labour market pressures - increasing the participation of older workers and easing the transition to retirement. New Zealand, Australia and the UK have legislation providing the 'right to request' flexible work arrangements, initially confined to employees with caring responsibilities, although some countries are extending these provisions (Department of Labour, 2011a and b).

Flexible work practices are already widespread in New Zealand. When evaluating the Employment Relations (Flexible Working Arrangements) Amendment Act 2007, it was found that a high proportion of requests are approved and only $56 \%$ related to caring responsibilities. The review of the legislation (Department of Labour 2011b) suggested that the right to request flexible working hours be extended to all workers. This proposal is still under consideration.

\section{Overseas policy initiatives}

\section{Holistic and adaptive approaches to workforce ageing}

In Europe, some countries have adopted a holistic approach to older workers' well-being, health and work-life balance (Maltby 2011; Moen and Sweet 2005). These concepts link with the Active Ageing approach, set out by Naegele and Walker (2006), who also discuss the concepts of Age Awareness and Age Management. Employability is based on the premise that education imparts key skills, careers advice and understanding of the world of work, so that workers can get into and stay in jobs and make transitions between roles. The concept of workability and the Workability Index was developed in Finland and envisages a proactive and preventive approach 
throughout working lives, to improve the quality of work and achieve better health through better age management at the enterprise level (Maltby 2011). The key is 'reciprocal adaptation' a process by which the individual seeks to establish a 'fit' with the job and the job is modified to suit the needs, values and interests of the worker as they age, with consequent benefits to the economy, enterprise, society and individuals (Yeatts, Folts and Knapp 2000).

\section{Incentives and promotional activities}

In some countries, businesses are given incentives to recruit older workers or job seekers (OECD 2006; Hirsch 2003; Brooke and Taylor 2005). The Australian Government has developed a range of resources and services to help employers attract and retain mature-age workers (defined as 50 and over). The Experience+Corporate Champions scheme provides financial assistance to employers to assess workforce demographics and develop action plans, including flexible working arrangements. The Restart wage subsidy provides financial assistance for employers who employ and retain eligible job seekers aged 50 or older.

The UK Government developed the Age Positive initiative in the Department of Work and Pensions as a programme of awareness raising and education aimed at changing attitudes within organisations (Walker 2006; H.M. Government 2009). Several schemes have been initiated under the European Social Fund, for example programmes for older ex-managers to update their skills and secure employment in organisations facing management skills shortages and to act as mentors for small and medium enterprises.

\section{Potential Policy Initiatives}

Active Ageing informants were asked to suggest priority areas for government action in response to workforce ageing.

\section{Information for employers}

Government is called upon to provide good information for employers and other stakeholders about the implications of population ageing and their effect on the future workforce, especially in terms of skill shortages. The aim would be to encourage employers to adopt policies and practices for keeping valued older workers on, but allowing them to do this for themselves. The respondents felt that information in the form of case studies, scenarios and best practice options, would serve this purpose, using appropriate channels such as business and management media and in-house newsletters. Small and medium-sized firms in particular need support and guidance.

\section{Education and Retraining}

Justification for investment in the education and (re)training of older workers can be found throughout the international literature (Llewellyn and Chaix-Viros 2008). So why are older workers often overlooked in training and education? McGregor, (2007, p.13) lists barriers to training for older workers, including lack of self motivation; fear of technical jargon; different styles and pace of learning. There are also employers' perceptions of high cost and limited time for a return on investment; and that older workers are seen as difficult to train and less willing. 
Appropriate training programmes will require recognition of prior learning, positive feedback and encouragement from employers (White 1999).

There was considerable support for government action on life-long learning among the Active Ageing respondents, with an emphasis on retraining for older workers. They felt that this policy is neglected in New Zealand; that recent actions such as cutting funding for adult education are wrong; and that there will be repercussions on productivity. There were calls for a good analysis of the skills needed for the future, with signals and support sent to tertiary education institutions, including ITOs; encouragement for workplace-based (re)training; special courses to improve computer literacy and technological abilities; training to allow unskilled workers from mid-career to move out of heavy manual work; retraining in areas such as nursing and early childhood education, which entail professional training, but are also stressful; and the extension of adult apprenticeship schemes or something like them.

The question remains as to where responsibility for the education and (re)training of older workers should lie. Some suggested it should be shared between employer and employees; others called for joint responsibility, or a three way responsibility involving employers, government and workers (and their unions).

\section{Consultation group on policy}

Despite some feeling that government should take a hands-off stance with business, there was support in for a think tank, task force, consultation group or specialised agency to advise on policy on workforce ageing. This would bring together stakeholders from all sectors, including voluntary agencies such as Grey Power and Age Concern. Such a body could suggest plans and programmes, and provide information and public education. Other suggestions included a Commissioner for Ageing and a dedicated Work and Age unit within MBIE.

\section{Incentives to employers}

While some Active Ageing respondents were aware of overseas initiatives, they have received little attention at the government level in New Zealand. Several private sector organisations have taken up the commercial Staying On programme and others are considering it, so such moves are clearly not wholly dependent on government encouragement or sponsorship (Pearman 2012). Clearly, age awareness campaigns must be linked to economic advantages for companies.

When asked if government incentives would be effective in New Zealand, the respondents were generally not enthusiastic. They were considered unnecessary and "tricky". Several said that older workers should be employed on merit only. Incentives could lead to resentment; would distort the market place and have unintended consequences. Instead, respondents called for other ways to make it less of a risk for businesses to take on older people, such as tax breaks for employers and retraining for older workers. Suggestions included: subsidies for older selfemployed people with good business plans; wage subsidies for set periods; mentoring schemes; and funding to develop age management strategies. Efforts by government to help business to engage and retain older workers, however, had to be suited to business rather than governmentimposed.

\section{Employment laws and conditions}


The Active Ageing interviews brought out calls for employment laws and contracts to accommodate different ways of working for older people, such as flexible and part-time work. Some respondents favoured bringing back a tripartite model, with a role for unions.

A particular issue is whether government policy should have a role in the process around retirement "conversations". There was little support for this and few specific policy suggestions. Some respondents felt attracted to the idea of requiring a "trigger" to promote discussion with employees about retirement or "staying on" options, as in the earlier UK situation (Flynn 2010).

\section{Action on age discrimination}

Findings from the literature and discussions with informants suggest that ageism is hard to tackle in the workplace and must be addressed on a wider basis. Legislation has its place as a sanction and a signal to society that age discrimination is not tolerated, but it is not the whole solution. The Australian Human Rights and EEO Commissioner (FitzPatrick 1999, p.7) concluded that "age-based stereotypes must be addressed by education and information as well as law and policy".

\section{Government as employer}

A common suggestion in the literature and also from Active Ageing respondents is that the public sector could act as a role model, initiating policies to encourage higher workforce participation among older people.

\section{Other policy ideas}

\section{Phased retirement}

Phased retirement is a way of balancing the aspirations and needs of older workers while prolonging some degree of workforce participation. An abrupt break between working full-time and not working at all is becoming less common. In New Zealand, Dixon and Hyslop (2008) showed that most people did not stop working on their 65th birthday but at a wide range of ages. The majority made at least one transition out of employment prior to their final exit. Among those who continued to work into their mid to late 60s, part-year and part-time employment is increasingly common. International research suggests that the majority of workers would prefer a gradual transition to retirement and that there are benefits for both workers and employers (Allen, Clark and Ghent 2004). For workers, reduced participation in paid work allows them time to pursue other activities and prepare for the financial changes which retirement brings. For employers, retaining older workers allows valued knowledge and experience to remain with the firm and be used to mentor and train less experienced workers.

Although the government can create an environment encouraging for older people to remain in paid work through its policies, legislation and regulation, the ability to retire gradually and with some degree of control on the part of workers will depend on employers' practices. 
Combining paid employment with eldercare is an emerging issue in New Zealand and internationally. Caring responsibilities influence decisions about workforce participation and retirement and are a factor in whether desired work status can be achieved. As life expectancy increases, many working people in their fifties, sixties and even seventies have living parents in their eighties and nineties, often in need of care and support. At the same time as governments are intensifying their efforts to extend labour force participation and delay retirement, they are also pursuing policies to support ageing at home ("in place") with reliance on informal care (Page at al 2009). Middle-aged women are frequently expected to and frequently do take on eldercare responsibilities. Yet this group has increased its level of participation in paid work and this is likely to continue.

Appropriate policy adjustments which acknowledge the economic as well as social value of unpaid caring work (McGregor 2007), flexible working conditions and caring leave, linked to employment contracts, will benefit working carers. A very strong need is for access to relevant and accurate information on eldercare services, especially from a consolidated source (Davey and Keeling 2004).

\section{Evaluation of government action}

As recognition of the challenges of population ageing and the benefits of prolonging workforce participation has become apparent, governments in many countries are developing policies to increase labour force participation by older workers and discourage early retirement. Commentators from the World Economic Forum (Beard et al 2012) suggest that public policy has been sluggish in adapting to the realities of workforce ageing. They call for high-level commitment; early and swift action at all levels; sharing best practice; and better use of resources.

Some of the existing policies in New Zealand, outlined above, provide a positive environment for extending workforce participation, even though this may not have been their original aim. Having a universal pension provides certainty about retirement income and is widely seen as equitable. The fact that there is no work-test on NZS provides the opportunity for superannuitants to have part-time paid work or income from self-employment to supplement it. This position is backed up by the fact that there is no compulsory retirement, although the myth of a "retirement age" persists and may influence choices. Government has a powerful policy lever in the form of the age of eligibility for NZS. Raising the age would provide a very strong incentive to remain in paid work. This is a measure widely adopted overseas but there is strong social and political opposition within New Zealand.

Existing human rights legislation provides a strong signal against age discrimination, but legislation is not the whole answer. Much wider action is needed, in the workplace but also in society at large, perhaps in the form of public education campaigns.

If older workers are able to access working conditions which suit them they are more likely to "stay on". New Zealand has legislation on flexible work and there is a strong case for its coverage to be widened. Access is, however, still at the employer's discretion, so that extending flexible working conditions may rely more on employers' decisions that any policy action. 
In other areas policy responses are less helpful in addressing the implications of workforce ageing. Education and (re)training for older workers requires urgent attention. The New Zealand Human Rights Commission (2010) in their National Conversation about Work call on government to: "urgently adopt a national programmatic approach to managing ageing workforce issues." McGregor (2007 p.9) pointed out that there has been a variable response to Objective 9 of the New Zealand Positive Ageing Strategy, which calls for the "elimination of ageism and the promotion of flexible work options." She calls for "an active integrated programme on ageing workers across the public and private sectors."

In order to explore their opinions on government action Active Ageing respondents were asked: "Do you think that the government is tackling the issue of workforce ageing effectively? " The general consensus was that they are not. Negative views were expressed by employers and business organisations. "Government is in the mindset that it is too hard to handle"; "(no action) at all compared to other western societies who are desperately thinking about it." Government and quasi-governmental agencies agreed: "Employment of older people is an issue for New Zealand - why don't we put more effort into it? There is no clear statement, no clear strategy on what government is trying to achieve"; "They recognise the problem but are doing nothing".

There were complaints that government is not consulting with business and other sectors. One business leader said: "We lack the civic institutions to allow the discussion on workforce ageing to take place. Government should talk to banks and big companies, who are getting concerned. When you get the sectors together with goodwill you can get agreement. We don't do enough of this." Other complaints concerned the relationship between business and government over employment matters and compliance. There were calls for government to take the lead in discussions about the future of the workforce, enabling employers to see their options to satisfy skills shortfalls, one of which is retaining older workers. A balance is needed between social justice and the business model, with "hard-nosed arguments about productivity to keep people in the workforce."

All in all, the report card on policy settings relating to workforce ageing in New Zealand is likely to conclude with a common school report statement: "Could do better".

\section{References}

Allen, S., Clark, R. and Ghent, L. (2004). Phasing into Retirement. Industrial and Labour Relations Review, 58.1. 112-127.

Brooke, L. and Taylor, P. (2005). Older workers and employment: managing age relations. Ageing and Society, 25.3. 415-429.

Beard, J., Biggs, S., Bloom, D., Fried, L., Hogan, P., Kalache, A. and Olshansky, S. eds (2012). Population Ageing: Peril or Promise. Geneva: World Economic Forum.

Department of Labour (2011a). Review of flexible working arrangements in New Zealand workplaces - survey findings. Wellington: Department of Labour.

Department of Labour (2011b). The findings of the review of Part 6AA of the Employment Relations Act 2000. Wellington: Department of Labour. 
Dixon, S. and Hyslop, D. (2008). The employment and retirement transitions of New Zealanders aged in their 60s: Evidence from LEED. Wellington: Department of Labour and Statistics New Zealand.

EEO Trust (2006). EEO Trust Work and Age Survey Report. Auckland: Equal Employment Opportunities Trust.

Flynn, M. (2010). The United Kingdom government's 'business case' approach to the regulation of retirement. Ageing and Society, 30.3, 421-443.

FitzPatrick, K. (1999) Anti-discrimination legislation and the older worker. Sydney: Australian Human Rights Commission.

Heathrose Research (2010). Report to the National Advisory Council on the Employment of Women, Wellington: Heathrose Research Ltd.

Hirsch, D. (2003). Crossroads after 50: Improving Choices in Work and Retirement, Joseph Rowntree Foundation, York.

Howse, K. (2006). Pension Reform and Age of Retirement Rules. Ageing Horizons, 5, 3-11.

Human Rights Commission (2010). What next? National Conversation about Work. Wellington: New Zealand Human Rights Commission.

Hurnard, R. (2005) The effect of New Zealand Superannuation eligibility age on the labour force participation of older people. New Zealand Treasury Working Paper 05/09, Wellington: The Treasury.

Harper, S., Khan, H., Saxena, A. and Leeson, G. (2006). Attitude and Practices of Employers towards Ageing Workers: Evidence from a Global Survey in the Future of Retirement. Ageing Horizons, 5, 31-41.

Keeling, S. and Davey, J. (2008).Working carers in New Zealand: zones of care and contested boundaries. Chapter 7 in Martin-Matthews, A. and Phillips, J. (Eds) Ageing and Caring at the intersection of Work and Home Life: Blurring the Boundaries. London: Psychology Press.

Leeson, G. (2006). The Employment Equality (Age) Regulations and Beyond. Ageing Horizons, 5, 12-19. Oxford Institute of Ageing.

Llewellyn, J. and Chaix-Viros, C. (2008). The Business of Ageing: Older workers, older consumers; big implications for companies. London: Nomura International Plc.

McGregor, J. (2001). Employment of the older worker. A project from Massey University funded by the Public Good Science Fund. Palmerston North: Massey University.

McGregor, J. (2007). Employment of older workers: Retirement Commissioner's 2007 review of Retirement Income Policy. Wellington: Human Rights Commission. 
Maltby, T. (2011). Extending Working Lives? Employability, Work Ability and Better Quality Working Lives. Social Policy and Society, 10.3, 299-308.

Moen, P., Sweet, S. and Swisher, R. (2005). Embedded Career Clocks: the case of retirement planning. Advances in Life Course Research, 9, 237-265.

MSD (2011). The Business of Ageing: Realising the economic potential of older people in New Zealand: 2011-2051. Wellington: Ministry of Social Development.

Murray, J. (2002). Age discrimination in employment: A review. EEO Trust, for the New Zealand Human Rights Commission. Auckland: Equal Employment Opportunities Trust.

Naegele, G. and Walker, A. (2006). A guide to good practice in age management. Dublin: European Foundation for the Improvement of Living and Working Conditions.

OECD (2006). Live Longer, Work Longer. Paris: Organisation for Economic Cooperation and Development.

OGC Consulting (2013). Coming of Age: The Impact of an Ageing Workforce on New Zealand Business. Wellington and Auckland: OGC Consulting.

Page, A., Baird, M., Heron, A. and Whelan, J. (2009). Taking Care: Mature age workers with elder care responsibilities. A background briefing paper. Sydney: Women and Work Research Group, University of Sydney.

Pearman G. (2012). An age-old issue - Tackling talent shortages and generational change involves challenging a few sacred cows. Human Resources Monthly, February 2012, 25-28.

Riach, K. (2006). Older workers: learning from three international experiences. Social Policy and Society, 5, 551-563.

Walker, A. (2006). Active Ageing in Employment: Its Meaning and Potential. Asian-Pacific Review, 13, 78-92.

White, J. (1999). Midwinter Spring: Smart Business and Older Workers. New Zealand Guide to Best Practice for Employers in an Ageing Population, Auckland: Equal Employment Opportunities Trust.

Wood, G., Harcourt, M. and Harcourt, S. (2004). The effects of age discrimination on workplace practice: A New Zealand case study. Industrial Relations Journal, 35, 359-371.

Yeatts, D., Folts, W. and Knapp, J. (2000). Older workers' adaptation to a changing workplace: Employment issues for the $21^{\text {st }}$ Century. Educational Gerontology, 26, p.565-582. 